\title{
THE ENVIRONMENTAL MANAGEMENT OF THE SEGARA ANAKAN LAGOON AND ITS SURROUNDINGS, CILACAP, CENTRAL JAVA - INDONESIA
}

\author{
Oleh: \\ Joko Christanto \\ Program Studi Pengembangan Wilayah Fakultas Geografi UGM \\ joko_yogya@yahoo.com
}

\section{$\underline{\text { Abstract }}$}

This paper is heavily drafted from a research conducted at Segara Anakan Lagoon in 2000. The lagoon is located on the south of Central Java coast and immediately to the northwest of Cilacap District, Central Java Province, and it is about $350 \mathrm{~km}$ southeast of Jakarta. The lagoon and its surroundings are marked by several distinctive features, including an extensive mangrove system, very rapid sedimentation, leading to progradation of the shoreline, strong tidal influence and the presence of many fish, crab and shrimp varieties. The main objective of the paper is to prepare the Segara Anakan environs so as to ensure that economically and socially valuable ecosystems are protected for the benefit of current and future generations. The method applied in the study was descriptive analysis of the collected secondary data to support the results of the study. The results of the study showed that commercial cutting and degradation of the mangroves must be controlled through related and concerned agencies, and there was a need to prepare more sustainable basis for conserving and developing the lagoon's resources in the future. On the basis of the study results, formulated recommendation is as the following: the mangrove forest need to be protected by preparing forest management guidance and instructions that can easily be accessed and operated by Kampung Laut people. Besides, the Kampung Laut people should have defined areas to be used for various purposes such as agricultural activities, ponds and regeneration areas. The mangrove forest in the surrounding Segara Anakan lagoon must be a protected zone, and the best option is likely by applying a community-based management. This emphasized local, village level, and control of resources utilization.

Key words: environment, degradation, lagoon, management, mangrove forest, Segara Anakan, Cilacap District and Central Java Province. 


\section{Background}

Indonesia The lagoon is a closely interlinked ecosystem comprising of open water areas, mudflats, salt marshes and mangrove forests offering niches and habitats for a wide variety of animal and plant species, and many of them endangered. It plays an important role in productivity of the coastal water of southern part of Central Java and hence supports economically to the livelihood of the people. The lagoon is one of the few remaining wetland areas in the region and offers roosting and nesting places for a number of stationary and migratory birds.

The shoreline of the Segara Anakan Lagoons has rapidly decreased during recent decades, especially after the explosions of the Galunggung Mountain in 1982. The accretion has been from the north to the south and from the east to the west side of the area. This rapid sedimentation is due mainly to sediment from Citanduy River and some other smaller streams. The effect of tides and currents on the morphology is a very quick change.

All islands and newly formed land in the Segara Anakan lagoon proved to be occupied by the same species found along the shoreline of the lagoon. The newly formed land is being inverted by mangrove species, of which Avicennia species are considered the chief pioneers (Soeryowinoto, 1980 in Agus Pudjoarinto, 1982, cited from Eric, C.F., 1982) along with Rizhophora. According to Hardjo Suwarno (1980, cited from Eric, C.F., 1982), at the mouth of the Donan River in the front zone of mangrove consists predominantly of Avicennia species, but in the mouth of Pekalongan River, Sonneratia species are dominants. Rujiman (1974) mentioned that around the mouth of the Alur Buntu River, the front mangrove zone is dominated by Zonneratia alba Smith. It is also considered that Sonneratia alba Smith also as the pioneer vegetation along the coast of the Segara Anakan area.

The mangrove forest of the Segara Anakan is now degrading due to the growing densely population of the forest surrounding areas leading to illegal cutting and conversion of the mangrove forest into settlement areas and other agricultural purposes. According to Wiryokarmodjo, et al., 1979, half of the mangrove forest in Kampung Laut has been ruined.

Poor upland soil management in the two watersheds causes considerable amount of sediments to be able to enter into the lagoon, bringing about a steady land accretion which overtime will completely engulf open water areas and wetlands. It is assumed that within a period of ten years, the lagoon might have been completely chocked by the sediments and will have ceased to exist. The area that will have been a highly valuable and productive ecosystem will be covered by sediments and will only offer marginal farmlands for rain fed agricultural practices. In a subsequent definition of current threats and disturbances that have an impact on natural site processes and site value, as may be seen that the major management issues of the Segara Anakan are: 1) high rate of lagoon sedimentation and reducing open water area and water volume caused by agricultural development activities in the catchments areas 
and poor area management; 2) steady loss of surrounding mangrove forest area the lagoon caused by poor management of the lagoon area and buffer zone; 3) uncontrolled aquaculture expansion of upland developments caused by poor lagoon area management; 4) uncoordinated and heavily impacting expansion of upland developments caused by poor buffer zone management; 5) uncontrolled and un-monitored pollution inputs caused by lack of management of the catchments area and from buffer zone (fertilizers and pesticides run offs from farming activities plus household wastes) and most probably, from aquaculture activities.

\section{Study Area and Location}

The Segara Anakan lagoon mangrove complex, commonly called Segara Anakan lagoon, is located on the south coast of Java and administratively The Segara Anakan is located in Kawunganten Sub-district, Cilacap, and Central Java. The Segara Anakan Lagoon consists of a central lagoon surrounded by mangrove swamps and recently accreted inter-tidal land that has partially been converted into rice fields. The central lagoon has remaining surface area of about $1,700 \mathrm{Ha}$ and is surrounded by an equal area of sloughs and tributaries, draining the mangrove swamps and inter-tidal land, respectively. There are about 12,230 Ha of mangrove forests, with varying degrees of disturbance, surrounding the lagoon. The Lagoon is connected to the Indian Ocean through two tidal channels, some $25 \mathrm{~km}$ apart, and is protected from the sea by the rocky Nusa Kambangan island (about $30,000 \mathrm{Ha}$ ) that runs parallel to the coast. The lagoon compound receives inflow from two major river basins: Citanduy Basin, with a catchments area of about 350,000 Ha; and the Segara Anakan Basin, with a catchments area of about 96,000 Ha, which drains to the lagoon via two principal rivers, the Cibeureum and Cikonde.

Geological view point

Van Bemelen (1949) stated that the coastal lowland belongs to the central depression zone of Java, the continuation of the Citanduy Depression. The eastern area, a broad coastal plain with almost flat topography, consists of beach sands, with intercalations of iron-sand pockets. The extent of the litho logy varies widely. The smooth coastline in this area indicates that marine processes are stronger than terrestrial influxes. Unlike the eastern area, where marine processes exceed terrestrial influxes, the area surroundings the Segara Anakan show that terrestrial agents play a dominant role in deposition. The Segara Anakan itself is a body of brackish water, situated north of Nusa Kambangan Island. This Island acts as a barrier protecting the Segara Anakan from the wave of the Indian Ocean currents, resulting in a low energy environment in the Segara Anakan. The Segara Anakan is connected to the Indian Ocean by two outlets, namely the western outlet and the eastern outlet. It also occupies the southeastern continuation of the broad alluvial plain in the Citanduy River, as well as from the Cibeureum flowing from the north. These condition resulted in continuous shallower and narrower of the Segara Anakan. If there are no countermeasures taken, it can be predicted that within a few 
Environmental Management of The Segara Anakan Lagoon and Its Surrounding, Cilacap, Central JavaIndonesia

decades the present estuary will be completely chocked with alluvium. At present, the tidal affected lowland surrounding the Segara Anakan is in the form of a mangrove swamp, crisscross by interconnected tidal channels and under lied by alluviums and swamp sediments in the form of clay and silt mixed with other organic materials.

\section{Geomorphologic Point Of View}

A coast, in particularly beach, is often a rapidly changing landform. The complexity of the forces initiating frequently rapid beach changes makes a proper analysis of coastal features difficult (Zuidam and Zuidam, 1978). The following main features influence the beach form: (1) beach material, (2) wave, (3) wind, and (4) tide. Human interference may have a huge effect on the beach, such as structures as harbors and piers modifying the natural movement of beach material so as to cause profound changes in the immediate vicinity and adjoining areas (Zuidam and Zuidam, 1978). Marshy or muddy land areas in the coastal zone, which are covered and uncovered by the rise and fall of the tide, are called tidal flats and these areas exist around the Segara Anakan. Typical of such flats are strongly curved, wide-open creeks and vegetation patterns. The vegetation differences causing such patterns are the result of differences in elevation, texture and water qualities. Beach ridges are continuous mounds of beach materials formed immediately behind the beach by wave action. Ridges may occur singly or in a series of approximately parallel deposits. Smoothly curved sandy beach ridges stretching continuously from Nusa Kambangan to Karangbolong, interrupted only by rivers, which enter the Indian Ocean, form the Cilacap region. Numerous older beach ridges, approximately parallel to the coastline of today, can be traced inland, and they record stages in shoreline progradation. They are absent from the Segara Anakan area, which was always protected from wave by the hill of Nusa Kambangan, and are best developed along those parts of the coastline most exposed to the South-East winds (Verstappen, 1975).

\section{Environmental View Point}

The Segara Anakan Environs are the only remaining extensive lagoon mangrove complex on Java. It is highly productive, supporting coastal fisheries that are of prime economic importance to the region. The ecosystem is made up of variety of major habitats; mangroves, silt water marshes, inter-tidal mudflat, and open water. It is the synergy of all of these habitats underlining the importance of its productive functions and environmental values, in particular its function as a major nursery ground for many of the economically important fish/shrimp species in the coastal waters. The true value of the wetlands has been long disregarded but is now being increasingly recognized. Wetland ecosystem is account for about six percent of the land area and is considered to be among the most threatened of environmental resources. Wetland ecological systems contain many animal/plant species, occupy key positions in natural resources production, and perform vital functions with regard to nutrient cycles and filtering tasks. They regulate water flows, provide a habitat for wild animals 
and birds and offer a rich variety of products for people living in/or near the vicinity. The Segara Anakan lagoon forms an ecosystem of considerable environmental and economic values. Freshwater and nutrients from the rivers mix with seawater and detritus mater (leaf litter) from the mangroves to forms a highly productive condition for both lagoon and marine life. The lagoon itself is a highly productive fishery but even more important, it is a nursery for shrimp and demersal finfish that are primarily caught in coastal water outside the lagoon.

\section{Socio-Economic Dimensions}

The lagoon has considerable cultural value and significance; people have lived here for more than hundreds of years. Due to the environmental destruction and man-made interventions the livelihood of these people and a valuable ecosystem will be inevitably annihilated if no action is taken. The lagoon is an important breeding and resting ground for endangered wildlife, and it supports the South Java shrimp fishery, which contributes substantial export earnings to the National Government (Based on the report of Department of Fisheries, the annual production reported at Cilacap is approximately 9,000 tons). Kampung Laut, in the Segara Anakan Lagoon area, consists of three villages and they are divided into eight hamlets. The first is Ujung Gagak Village, which covers two hamlets namely Karanganyar and Cibeureum. The second one is Panikel Village, which comprises of three hamlets Muara Dua, Bugel and Panikel and the third Ujung Alang Village another three following hamlets Motean, Klaces (in Nusa Kambangan Island) and Ujung Alang Baru.

Demography

Among the villages, the most densely populated is Panikel. Table 1 shows settlement areas, village population and population density

\begin{tabular}{|c|l|c|c|c|}
\hline No. & Village & $\begin{array}{c}\text { Settlement Area } \\
(\mathrm{Ha})\end{array}$ & Population & $\begin{array}{c}\text { Population Density } \\
\text { (No. of Persons/ha) }\end{array}$ \\
\hline 1. & Ujung Alang & 452.6 & 4,391 & 10 \\
\hline 2. & Ujung Gagak & 184.2 & 3,673 & 20 \\
\hline 3. & Panikel & 132.9 & 3,679 & 28 \\
\hline \multicolumn{2}{r|}{ Total } & 769.7 & 11,743 & 15 \\
\hline
\end{tabular}

Source: Monografi Desa, 1997

The in migration rate into the Kampung Laut is very low. On the other hand, a high rate of out migration has been started since the 1980's, mainly of young people who have looked for employment elsewhere. Most of the inhabitants were born in their villages. Only a negligible number of persons have migrated into Kampung Laut during the recent years.

Level of Education

The existing few schools is confined to the primary school level, and has been extended moderately to encompass most hamlets. Due to the instability of some of the newly accreted soil base, several of school buildings have been damaged, and after being repaired several times, are in a few cases no longer 
Environmental Management of The Segara Anakan Lagoon and Its Surrounding, Cilacap, Central JavaIndonesia

occupied. There are 12 schools in total, 9 elementary and 3 junior high schools located in Ujung Alang (4 units); Ujung Gagak (4 units); and Panikel (4 units). Some teachers working in Panikel commute daily from Kawunganten, a practice that reduces the effective hours spent for teaching. The educational attainment of Kampung Laut inhabitants of Kawunganten Sub-district is shown in Table 2.

Table 2. Educational Attainment in Kampung Laut

\begin{tabular}{|l|l|r|r|r|r|r|r|r|r|}
\hline \multirow{2}{*}{ No } & \multirow{2}{*}{ Level of Education } & \multicolumn{2}{|c|}{ Ujung Alang } & \multicolumn{2}{|c|}{ Ujung Gagak } & \multicolumn{2}{|c|}{ Panikel } & \multicolumn{2}{|c|}{ Total } \\
\cline { 3 - 10 } & & No & $\%$ & \multicolumn{1}{|c|}{ No } & $\%$ & No & $\%$ & \multicolumn{1}{c|}{ No } & \multicolumn{1}{c|}{$\%$} \\
\hline 1. & Elementary School & 452 & 73.2 & 256 & 61.7 & 296 & 65.6 & 1,872 & 61.4 \\
\hline 2. & Junior High school & 99 & 16.0 & 99 & 23.8 & 94 & 20.8 & 833 & 37.2 \\
\hline 3. & Senior High school & 62 & 10.0 & 56 & 13.5 & 58 & 12.9 & 328 & 10.0 \\
\hline 4. & Academy/University & 5 & 0.8 & 4 & 1.0 & 3 & 0.7 & 12 & 0.4 \\
\hline & Total & 618 & 100.0 & 415 & 100.0 & 451 & 100.0 & 3,045 & 100.0 \\
\hline
\end{tabular}

Source: Monografi Desa, 1997

Most Kampung Laut inhabitants of Segara Anakan graduated only from elementary school, and very small percentage obtained an academic degree. The illiteracy rate was estimated to be $30 \%$ and still appears to be the case. However, this relatively high percentage is most likely due to the fact that younger people with formal education used to leave their village. According to preliminary conducted interview, there was a change in perception and attitude regarding higher education. Many of the young generation were aware that by obtaining higher formal education they could improve their income and standard of living. This group is most likely to emigrate as soon as individuals achieved an adequate educational attainment.

Income and Livelihood

The primary source of income for local people is the lagoon fisheries, which have decreased from time to time. There is an engagement in new income sources like farming, mangrove lumber and labor, but the options are limited.

The average level of per capita household income of the villagers in the area generally does not meet the minimum basic needs. According to the head of village (Kepala Desa), average monthly income/capita of Ujung Alang's inhabitant was less than Rp 150,000.00 (One hundred fifty thousands Rupiah). Whereas, average monthly income/capita of Ujung Gagak's dweller was much higher, reaching Rp 450,000.00 (Four Hundred and Fifty Thousands Rupiahs). Panikel, on the other hand, was certainly the most impoverished village of the Kampung Laut. Here, most villagers are depending on marginal rain fed farming. The low level income of the Kampung Laut people was caused by almost all people in the area worked and were employed in some capacity, but underemployment was still a problem. In other words, there were not many 
optional jobs for them. Fishing was the almost common livelihood, but this was seasonal and depended on the weather and environmental conditions.

The accretion of land and subsequent growth of the islands allowed more farming and gardening activities. Small scale of farming augmented food supply for local consumption but contributed little in income generation.

Flooding and inundation of hamlets and agricultural lands poses a persistent problem in the perception of villagers in Panikel. During the last two years they were unable to cultivate rice, and most of them must find other sources of living outside the lagoon. They recalled the flood about 12 years ago that left their land covered with $1.5 \mathrm{~m}$ of mud and caused 8 deaths among them. A decade ago, they suffered an acute famine and had to be supplied with food by a private organization.

Table 3. Main Occupations of Household Heads in Kampung Laut

\begin{tabular}{|l|l|r|r|r|r|r|r|r|r|}
\hline & & \multicolumn{2}{|c|}{ Ujung Alang } & \multicolumn{2}{c|}{ Ujung Gagak } & \multicolumn{2}{|c|}{ Panikel } & \multicolumn{2}{|c|}{ Total } \\
\cline { 3 - 10 } No. & Occupation & No. & \multicolumn{1}{c|}{$\%$} & \multicolumn{1}{c|}{ No. } & \multicolumn{1}{c|}{$\%$} & \multicolumn{1}{c|}{ No. } & \multicolumn{1}{c|}{$\%$} & \multicolumn{1}{c}{ No. } & \multicolumn{1}{c|}{$\%$} \\
\hline 1. & Fishing & 936 & 29.3 & 779 & 32.0 & 483 & 16.7 & 2,410 & 22.8 \\
\hline 2. & Farm Labor & 603 & 18.9 & 491 & 20.2 & 796 & 27.5 & 2,465 & 23.4 \\
\hline 3. & Farming & 893 & 28.0 & 674 & 27.8 & 978 & 33.7 & 3,327 & 31.5 \\
\hline 4. & Other Labor & 193 & 6.1 & 69 & 2.8 & 143 & 4.9 & 503 & 4.8 \\
\hline 5. & Civil Service & 20 & 0.7 & 24 & 1.0 & 21 & 0.7 & 82 & 0.8 \\
\hline 6. & Others & 545 & 17.0 & 391 & 16.2 & 477 & 16.5 & 1,767 & 16.7 \\
\hline 7. & Total & 3,190 & 100.0 & 2,428 & 100.0 & 2,898 & 100.0 & 10,554 & 100.0 \\
\hline
\end{tabular}

Source: Monografi Desa, 1997

The Table 3 tells that fishing is the dominant income source in Ujung Alang and Ujung Gagak, whereas in Panikel, farmer is the main occupation. Due to decreasing fishing ground in the lagoon, some people were in the process of shifting from fishing to farming.

Health Standards and Sanitation Facilities

Although the health standard in the villages had apparently improved slightly since the time of the report by White et al., (1989), the sanitation and health situation in the villages within Segara Anakan environs was still very poor. All villages suffered from lack of sanitary facilities and supplies of potable water, with the exception of Klaces on Nusa Kambangan. The problem was compounded during dry seasons. In Ujung Alang, water was piped from Nusa Kambangan, the underwater pipe, however, was frequently hit by a ship and damaged in the process. It has not been repaired yet, reportedly due to lack of funds. Potable water is now ferried from Nusa Kambangan, a trip of more than 3 hours to Ujung Gagak.

Socio-economic impacts are positive and arise from the interventions that inhibit further loss of the lagoon's resource base and introduce group strategies, through village organizations and women groups, for more 
sustainable management of the lagoon's resources. They also arise from specific interventions to improve village infrastructure, access to facilities institutional and legal frameworks, and income generating opportunities.

\section{Accessibility, Means of Transport}

The sole mean of communication within the lagoon was water transport. A number of privately operated boats served the Kampung Laut and provided transportation services on call for passengers and goods, together with public transport boats. The water way between Nusa Kambangan and Mudflats and Islands in the Lagoon is the thoroughfare for large car ferries that communicate between Cilacap, Majingklak and Kalipucang.

\section{Research Method}

The Objective of The Study

The general objective of the study is to prepare the environmental management model of the Segara Anakan lagoon and its surroundings so as to ensure that economically and socially valuable ecosystems are protected for the benefit of current and future generations.

The Applied Method

The method of the study is an analysis of the secondary data. The secondary data are data, which obtained from various institutions, such as: constitutes media, government report, completed project reports/documents, governmental or ministerial statistics, completed project reports, brochures, proceedings of conferences, workshops etc. The secondary data were obtained from various sources, namely: library, newspaper, and related institutions. In order to come up with the study results, a descriptive analysis and cross tabulation of the secondary data were applied. It was expected that the results could be applied for Segara Anakan management.

The Scope of The Study

The scope of the study covers the following items: (1) create a basis for sustainable management of natural resources in and around the Segara Anakan Lagoon, and (2) stabilize the offshore fisheries, which largely depends on the existence and ecological soundness and functioning of the Segara Anakan Lagoon.

\section{Result and Discussion}

The Changes of the Water Body and Mangrove Forest

In 1903, the lagoon's water surface was estimated to be about $6,450 \mathrm{Ha}$; it is now about $1,700 \mathrm{Ha}$. In 1930, the mangrove forest was about $35,000 \mathrm{Ha}$ of robust trees; it is now about $12,000 \mathrm{Ha}$ of which only about 5,600 Ha remains in slightly too moderately disturbed conditions. Without any intervention, it has been estimated that, in less than ten years, the lagoon would be completely filled in leaving behind swampy lands that would eventually be converted into low yielding rain fed rice fields on marginal soils. The remaining mangrove forests would rapidly disappear due to lack of sustainable management 
systems and would eventually be cut down by outsiders or by a subset of farmers/fishermen searching for a ways to increase their incomes. If the lagoon were lost, it would be impossible to reinstate its environmental integrity. The lagoons provides habitat for 85 species of birds, as well as sea otters, other aquatic fauna, deer, monkeys and several small mammals.

The Presidential Decree No. 32/1992 was the basis of mangrove reforestation, which demarcated landward zones: $50 \mathrm{~m}$ wide from rivers, and $100 \mathrm{~m}$ from coastlines. If implemented, the areas along the rivers in Segara Anakan lagoon would cover approximately 2,800 $\mathrm{Ha}$. Another document to be applied in the mangrove forest reforestation and management program of the Segara Anakan lagoon and its mangrove forest is the Mangrove Charter, because the government of Indonesia principally recognized the importance of mangroves.

The mangrove area around Segara Anakan was unique and particular in a global context: according to large number of investigations in other part of the world (Hutchings and Saenger, 1954; cited from ECI, 1994), above ground biomass was the range of 60 to $200 \mathrm{m3} / \mathrm{Ha}$. The highest reported value was 235 m3/Ha. The Segara Anakan Ecology Team (1984) estimated biomass value of up to $590 \mathrm{~m} 3 / \mathrm{Ha}$ or more than twice the highest value found elsewhere in the world.

The most urgent problem of the mangrove forest around the lagoon was its over-harvested status and the partial devastation. A sign of the over utilization was the fact that villagers now return to harvest buttress roots of Hiritiera littoralis for charcoal burning following tree cutting, and likewise harvest were real roots of Rhizophora spp.

On the contrary to the open-access areas in the west lagoon, the condition of the protected zone in the eastern part of generally good by comparison. However, even this protected forest (hutan lindung), which was supposed to be protected, holds no large trees but must rather be said to be in stage of healthy, early re-growth (source: direct information obtained from Perhutani Cilacap, and observation from the project).

The Challenges to Improve Standard of Living

One of the challenges in achieving improved standards of living in developing countries including Indonesia, and more specifically in the Segara Anakan Lagoon (Cilacap, Central Java) was to increase agricultural and fisheries productivity without aggravating environmental degradation. In terms of rapidly growing populations, productivity of land must not only be preserved but must also be increased to meet the demands for food and fiber. Java is blessed with a rare combination of soils and climate that can support some of the world's highest rural population densities. But even Java is stretching the limit of carrying capacity of its deep soils and ample rainfall.

Farmers on the margin of agricultural society have traditionally relied upon shifting cultivation to produce crops on lowland and sloping lands. Under conditions of low population density and long fallow period, shifting cultivation 
can be a sustainable form of agriculture. If population growth and competition for resources shorten the fallow periods and prevent the return of the forest, then the forest ecosystems will degenerate. The intensive use of tropical rain forests is often followed by human impoverishment and by the loss of millions and millions of years of evolution, not only a plant, fish and animal species, but also of the most complex biotic communities in the world. When pressures of increasing populations and growing demands by lowland interests for upland resources (plantations, forest products, water, hydropower, and recreation) constrict the agricultural land based, then shifting cultivators must become settled, sedentary farmers. If this transition from shifting cultivation to permanent agriculture is not accompanied by sustainable farming systems then it will come up with environmental degradation and worsening poverty.

This Citanduy watershed is located in the southern part of West Java Province and covers around 446,000 Ha (including the Segara Anakan subwatershed) of heavily dissected mountains, steep slopes, and flat alluvial areas. Approximately half of the Citanduy watershed rolls hill country, with the remaining half almost equally divided between mountainous area, mostly under $1,000 \mathrm{~m}$ in elevation, and alluvial plains. The population is estimated to be about 3.4 million, for a density of 760 persons/ $\mathrm{km} 2$ although the density of the Citanduy basin is slightly higher.

The Segara Anakan Basin extends from the Sidoarjo lowlands, and the origin of Cikujang River in the west, to the Jeruklegi Rivers in the east, and from the headwaters of the Cihaur River in the North to Nusa Kambangan Island in the south. The Segara Anakan and its environs cover about 96,000 Ha. The Segara Anakan area consists principally of hydromorphic alluvial soils, dark gray alluvial soils, and a small area of red latosols. Most of the geologic units in the Segara Anakan Basin are composed of volcanic materials except for the reef limestone and marine sediment near the Segara Anakan Lagoon.

The residual soils in the hill areas, which make up about 85 percent of the Citanduy watershed, are being eroded by rainfall impact and by stream channel cutting. The various rivers in the watershed to the alluvial plain transport these sediments. Average sediment yield is estimated at about 5 millimeters/year. Landslides and other mass movements of soil and loose rock that reach active watercourses are also a significant source of sediment as are mining operations near the riverbank. The filling rate has increased to such extent that the surface area is estimated to decrease from the current 1,400 Ha to about $550 \mathrm{Ha}$ by the year of 2000 ( $E C l, 1987)$. Management in the area must focus on viable alternative income sources such as appropriate aquaculture, offshore fishing, simple farming, animal husbandry and, possibly, home craft. Land and water tenure was also an increasing concern, especially if the people were to have a hand in the management strategy for limited uses and control of fishing methods. The fishing right system and land resource use system for mangroves and farm lands can be developed. Education is one of the integral parts of this process (Alan T. White et al., 1989). 
Fisheries (present conditions and key issues)

Between 10 and 30 percent of the Kampung Laut population engaged in fishing as their main income source. Caught fish amounted of 20 to 40 percent of the catches, and the rest were crustaceans. Shrimp catches consist mainly of juveniles caught in tidal traps, gill nets and cast nets. Catches and average catch rates from the lagoon have steadily decreased during the recent years. The reasons were water volume reduction of lagoon filling and subsequent, over fishing and over harvesting. Destructive fishing gears such as fine meshes nets with mess sizes of $4 \mathrm{~mm}$ and less are common (e.g. local fishing gears called apong, wide tadahan; White et al., 1989). This practice constitutes an acute danger to the required rejuvenation of exploited fish stocks in the lagoon and in a near shore and offshore waters. Consequently, the fishermen faced increased fishing pressure like decreasing catches, and they tent to change their orientation the southern coast of Nusa Kambangan Island. Some of these fishermen used homemade diving equipment and apply pesticides in the capture of lobsters.

Fisheries regulations and laws applicable to the fishery in Segara Anakan that are existent and supposedly in force refer to a minimum mesh size of 25 $\mathrm{mm}$; the use of destructive fishing such as poisons and explosives is considered a criminal offence. Other regulations regarding fishery that are in force are the establishment of a task force to control the use of destructive fishing gear and to deliver extensions services (Bupati Decision No. 253/1987). Cilacap District Level Fishery Service Office (Dinas Perikanan Cilacap) headed the task force and representatives from the private sectors supported it. The same decision affects the prohibition of jaring arad in the lagoon. Other relevant regulations concerning the establishment of licensing team of brackish water fishponds development was the Decision No. 503/1988.

The key issue on the Segara Anakan fishery was to find a better management of the fishery to optimize both within Segara Anakan as a spawning and nursery area. At present, key constraints of proper management are: (1) limited ecological understanding on the relationships between ocean and lagoon fisheries; (2) lack of accurate fishery data; (3) very limited fishery management system in making management decisions and enforcing them.

\section{Aquaculture}

The favorable conditions of the lagoon and limnic environment on the western part attracted considerable past and present development of shrimp farms. According to the information given by Project Management Office (PMO) of Segara Anakan Conservation and Development Project, a high yet unknown percentage of farms have developed without any licenses or clearance from either Perhutani or Kabupaten (district). About half the farms are under semiintensive or modified intensive management regimes, where aerators are used to allow high stocking densities. Despite such technical facilities and inputs, more or less all farms seem to be rather poorly managed. 


\section{The Development for The Segara Anakan Area}

The development process of the Segara Anakan was located on the left of Citanduy River Basin. Citanduy River Basin drains into the Segara Anakan; any change in Citanduy River morphology will influence the Segara Anakan Lagoon area. The capacity of the Segara Anakan Lagoon was rapidly decreasing due to sedimentation and consequently decreased in the Segara Anakan Lagoon depth and it would affect Cilacap Ocean Port. The Sidareja-Cihaur plain and the Segara Anakan tidal swamp area have a high potential for agricultural use. Aside of the previous description, the Citanduy River Basin comprised of the Citanduy, Cimuntur, Cijolang, Cikawung and Ciseel sub-river basins with an area of 446,000 Ha. Segara Anakan has a great potential for land and water resources development. The optimal utilization of land, water and human resources in the Segara Anakan along with the development of the Citanduy area could be best achieved by plans considering the project as a single river basin development scheme.

The following plans for the Citanduy River Basin of 446,000 Ha were presented in chronological order from the earliest known (M. Napitupulu et al., 1982):

- In 1933, prior to the World War II, the West Java Public Works Office (2e District Verkeer \& Waterstraat 1938) proposed a scheme for flood protection and utilization of the Citanduy River Basin Water by the construction of strategic flood diversion structures. From the study of the aerial photographs, it can be seen that some of the proposed measures were put into effect with considerable benefit. The old channel improvement measures were particularly easy to locate on the photographs.

- Blommenstein (1948) proposed a plan for control the lower Citanduy System as well as the reclamation of the Segara Anakan Area. Under the Blommenstein plan, the Segara Anakan and the surrounding tidal forest was to be converted into a big polder $(30,000 \mathrm{Ha})$ by making levees of the Citanduy River on both sides and diverting the Citanduy River Discharge directly into the Indian Ocean. The Segara Anakan inlets from the sea were to be closed by means of cut-off levees located at the eastern and western outlets to the sea and the resulting polder was to be drained by pumping. He envisaged that local rainfall and irrigation water would flush the salt water and eventually the area could be used for productive agriculture. For the development of irrigation from the Cidanduy River, the Blommentstein proposal included the diversion of a portion of the Citanduy River flow for irrigation purposes in Lakbok area of West Java, and a second diversion for irrigation purposes in the Sidareja area of Central Java.

- PT. Indah Karya Consultants (1969) were commissioned to draw up a comprehensive development program for the Citanduy River Basin. This study proposed that diverting the flood flows of the Citanduy River to reclaim the Segara Anakan area. The diversion schemes were purposed at (a) Cilongkrang, to divert a maximum of $100 \mathrm{m3} / \mathrm{second}$ from the Citanduy River to the Segara Anakan via Cibeureum River and (b) at Nusawuluh, to divert maximum of 200 m3/second from the Citanduy River via Cikujang 
River. In both cases the diversion had a dual purpose, namely decreasing flood discharge in the Citanduy River and accelerating sedimentation for the reclamation of the Segara Anakan area.

- In 1975, as part of Master Plan Study of the Citanduy River Basin, Engineering Consultants Inc. $(\mathrm{ECl})$ proposed the reclamation of the Segara Anakan lagoon, the tidal swamps, and the marshes by a combination of cutoff levees in Segara Anakan outlet provided with gates. This proposal (RCl 1975 a, 1975 b, Turner 1975 and Marr 1976) would virtually prevent saltwater intrusion from the ocean and would create, within a determined range of elevations, a fresh water lake (coastal reservoir). In addition to reducing sediment inflow into the Segara Anakan and maintaining reasonable capacity, it was proposed to divert the Citanduy River directly into the Indian Ocean.

- In June 1976, as a result of further study, E.C.I. (1975 c) issued report, "Segara Anakan Special Re-evaluation of Sedimentation". The following conclusion quoted from that report: "The recently obtained surroundings of the Segara Anakan indicate that the volume has decreased in five years to 50 percent (56 MCM) of the 1971 value (112 MCM). By the time construction can be completed and the project put into operation the fresh water reservoir (coastal) will have diminished to a size too small to accomplish the project objective. Therefore, it is the recommendation of the consultant that the sub-project as described in 1975 feasibility report be radically revised".

- During the period of 1976 - 1978, after the abandoning of the Segara Anakan reclamation Sub-project, The Citanduy River Basin Project proceeded with the implementation of the other three aspects of water resources development, namely: (a) designing a flood control scheme for the lower Citanduy - Ciseel Basins; (b) undertaking a feasibility study for the upper Watershed Conservation Program; (c) designing and rehabilitating various new irrigation drainage schemes, namely rehabilitation of seven existing irrigation projects (13,000 ha) located in the Lower Citanduy-Ciseel area, and feasibility studies and design of several new irrigation projects: Penulisan (600 ha), Banjar Plains (795 ha), and Sidareja-Cihaur (20,400 ha). Specifically, the Sidareja-Cihaur irrigation area covers the Sidareja and Cihaur (East Sidareja) areas and a part of the Segara Anakan area, which had already been converted into rice cultivation.

- In October 1979 Blommenstein (1979) again recommended the reclamation of Segara Anakan and its environs by creating a polder in "A comprehensive plan for the development of the controlled irrigation systems in Java and Madura" which was submitted to the Department of Public Works.

- Subsequently, The Asian Development Bank was committed to promoting environmentally sustainable economic development. Based on the chronological shown since early 1930's, several study teams have different purposed plans for the lagoon. There had been a general shift from reclamation objectives to conserve the Segara Anakan lagoon mangrove system in sustaining the lagoon and offshore fisheries. 


\section{Tourism Plan}

The Integrated Management Plan for Segara Anakan, Cilacap, Central Java, Indonesia (ASEAN/US, 1992) and ECl (1987) reported on the tourism potential of the area. According to the report, 13,987 foreign and 63,457 domestic tourists visited the area, mostly on their way (by ferry) from Cilacap to Pangandaran, a beach resort located on a small peninsula $10 \mathrm{~km}$ to the west of Segara Anakan. Only limited attempts had been made to develop the area into a tourist destination. With proper management and government support, the area possesses a good potential for domestic and international tourism development. The tourism Authority of Central Java had designed a master plan (1998) for the conversion of Nusa Kambangan into a tourist destination. Major potential attractions were: (1) Kakangbandung beach on Wijaya Kusuma Island; (2) Permisan Beach and Pasir Putih on Nusa Kambangan Island with their white beaches; (3) a number of caves with an attractive fauna; and (4) Indralaya passage with its unique coastal system.

The plan prioritized eco-tourism over "un-natural" tourism in the sense of large areas of the islands would be under protective management and conservation and that development of tourism of tourism facilities were strictly limited to a certain areas.

\section{The Plan for Reducing the Lagoon Sedimentation}

Details of the interventions were discussed in ECl (1994). The Citanduy diversion would reduce the lagoon sedimentation by about 95 percent; with the other 5 percent still being carried into the lagoon by tidal currents. The rationale behind the planned Cikonde diversion was to expedite sediments transport out of the lagoon before the time to settle by accelerating water flow and hence sediment transports. The diversion would reduce the total sediment load of the lagoon to level that will be manageable by means of an annual dredging program. This was actually very controversial because of the dumpsite locations would be in areas that were very suitable for mangrove rehabilitation and reforestation.

The main, if not the only cause of the degradation of the Segara Anakan was certainly the uncontrolled erosion in the upper watersheds on the river system. Increased erosion is inevitable consequence of hillside farming. The degree of erosion was dependent on the slope of the land, the rainfall erosive characteristics of the soil, patterns of rainfall, and the farmer's agricultural practices. As a result, upland farmers needed a significant cost in adopting soil conservation measures and changes in farming system, they were unlikely to make changes in their land management unless they can see an economic advantage in doing so. Upland farmers were presently dependent on low return cropping systems, such as maize or cassava, and they might be aware that soil erosion had reduced their productivity, but might not be able to afford conservation measures. For annual crops such as maize and cassava, terracing 
could reduce erosion but without substantially raising profitability. At the other extreme, farmers with very profitable crops that are highly erosive, such as temperate vegetables grown on deep, highly productive volcanic soils on steep slopes might not consider soil conservation if their returns were not affected by soil erosion.

As outlined above, a participatory approach in the lagoon area was an instrumental for the success of the Segara Anakan lagoon's sustainable management. The awareness campaigns and participatory inputs would also be the instrumental in assessing the willingness of the beneficiaries to actually pay for the various benefits they received.

The participation of the local government, NGOs and the community would undoubtedly be a crucial part of the management plan and follow up activities. It did not preclude participation and support of the central government, but because of the local resource use conflicts nature, people should have been agreed to change their ways. Law enforcement should not the only means of changing use patterns. The very large impact on the physical environment would only stabilize with significant national support, planning and coordination with the upper River Basin Projects and land use arrangements.

Micro level sustainable mangrove management has to be prepared through the efforts in reducing wood-cutting level in the lagoon, through local participation and group management, and to encourage rehabilitation and upgrading of existing mangroves and viable management options providing higher incentives to local residents.

One approach would be to resurrect and redirect local traditions of common property management in rice field (sawah) formation and fisheries. Small groups at the hamlet level could be given responsibility for managing specific segment of mangrove forests, and in particular those within the vicinity of their residential areas. A second challenge would be to develop techniques and incentives for rehabilitation and sustainable management.

\section{Conclusions}

The natural resources of coastal marine areas were unlike their terrestrial counterparts and therefore required different forms of management, for example: coral reefs, beaches, coastal lagoons and inter-tidal mangrove forest have no counterparts in terrestrial resources. Threats to the productivity of these unique resources systems arose from development activities and their side effects, such as reef and beach mining, shoreline filling, lagoon pollution, sedimentation, and other activities that were distinct from those on land. There was a need for the coastal area management as a unit by integrating the management process with all appropriate economic sectors.

The mangrove forest in Segara Anakan needed some forms of protection, the mixed brackish water culture (Tumpang sari tambak) project could be 
extended by following the prepared plans with guidance and instructions in forest management for the Kampung Laut people (Ujung Alang, Ujung Gagak, Panikel Villages) and its surrounding, defined areas for their economic activities should be available. For example for agricultural purposes, ponds, and regeneration areas; the mangrove forest in Karanganyar (Ujung Gagak) should be made as a strictly protected forest because the mangrove natural regeneration there was the best. Some considerations must be taken into account because of their major impacts: agricultural pollution, siltation from eroded uplands and excessive cutting of mangrove for fuel.

Environmental stability affected the community stability and community stability affected diversity. Consequently, the general sustainable management of the Segara Anakan environs would play an important role, and the preparation of detail sustainable management should be based on the paradigm of the sustainable development, with a special attention has to be given to a transparent presentation and unrestricted accessibility of information to the residents of the Kampung Laut.

It was strongly recommended that shrimp farms operating in the lagoon will be properly charged, in form of fees, for the environmental damage they have caused to the lagoon and its environment. Two type of brackish water ponds operations must be differentiated: traditional, low inputs, low investment farm under extensive management that were exclusively operated by local residents versus high input, high investment semi-intensive farms that were operated by outside investors.

\section{References}

ADB (1992) Mangrove Forests. A Valuable but Threatened Indo Pacific Resource. Staff Paper No. 5. Asian Development Bank. Manila. Philippines.

ADB (1998) Project Administration Memorandum of Segara Anakan conservation and Development Project in Indonesia. Asian Development Bank. Manila. Philippines.

ADB and Republic of Indonesia, Ministry of Forestry (1997) Institutional Strengthening of The Forest and Soil Conservation Services in The Segara Anakan Basin Project (TA. No. 2665 INO). Asian Development Bank. Manila. Philippines.

ASEAN/US (1992) The Integrated Management Plan For Segara AnakanCilacap, Central Java Indonesia. ICLARM Technical Report No 34. ASEAN/US Coastal Resources management Project. Directorate General of Fisheries, Jakarta. Indonesia/ICLARM, Manila. Philippines. 
DWRG (1976) Segara Anakan Special re-Evaluation of Sedimentation, Directorate of River. Ministry of Public Work and Electric Power.

ECI (1974) The Citanduy River Basin Development Project. Master plan Annex $\mathrm{H}$ : Land Use and Management. Ministry of Public Works and Electric Power. Directorate General of Water Resources Development. Directorate of River and Swamps.

ECI (1994) Segara Anakan Conservation and Development Project. Final Report. Technical Report of ATC Engineering Consultant Inc. (ECI). Delft Hydraulics - PT. Exsa International Co. Ltd. Asian Development Bank Institute of Hydraulic Engineering. Ministry of Public Work.

Ecology Team (1984) Ecological Aspects of Segara Anakan in Relation to Its Future Management. Technical Report of Institute of Hydraulic Engineering, Ministry of Public Works in Cooperation with Ecology Team. Faculty of Fisheries, Bogor Agricultural University.

Eric, C.F. Bird, et al.,. (1982) Proceedings of the Workshop on Coastal Resources Management in the Cilacap Region - with Research Reports. The Indonesian Institute of Science and the United nations University. Jakarta.

Kvalvaghaes, K. (1980) Marine Survey Report of Segara Anakan/Nusa Kambangan Area. Field Report of UNDP/FAO National Parks Development Project. Bogor.

Ludwig, H.F. (1984) Final Report of Consultant (Phase 1 Report): Segara Anakan Environmental Monitoring and Optimal Use Planning Project. Institutes of Hydraulic Engineering, Agency for Research and Development, Ministry of Public Works.

Napitupulu, M. and Ramu, K. ( 1980) Development of Segara Anakan in Central Java. Citanduy Project Office, Banjar. Indonesia. Directorate General of Water Resources Development (DWRG). Ministry of Public Works and Electric Power.

Rujiman (1974) Studi Vegetasi Hutan Payau di Cilacap Petak 28. Skripsi Sarjana. Fakultas Kehutanan, Universitas Gadjah Mada, Yogyakarta.

Van Bemmelen, R.W. (1949) The Geology of Indonesia, Vol. I A. Govt. Printing Office. The Hague.

Verstappen, H. Th. (1975). Landforms and inundations of the lowlands of South Central Java: ITC Journal (Serayu-Valley Project) 2:65-74.

White, A.T., Purwito, M. and Sadora, M.S.M. (1989) The Coastal Environment Profile of Segara Anakan.Cilacap, South Java. Indonesia. ICLARM 
Technical Report No. 25. ASEAN/US Coastal Resources Management Project, Directorate General of Fisheries, Jakarta, Indonesia. Jakarta. ICLARM, Manila. Philippines.

Wiryokarmojo, H., S.D. Soeroso, and Bambang Kartiko (1978). Pengelolaan Hutan Payau Cilacap. Dalam Prosiding Seminar Ekosistem Hutan Mangrove. Lembaga Oceanologi Nasional - LIPI, Jakarta: 72 - 80.

Zuidam, R.A., and F.I. Zuidam (1978). ITC Textbook of Photo Interpretation. Vol. VII: Use Serial Detection in Geomorphology and Geographical Landscape Analysis. 